\title{
The assault on universalism: how to destroy the welfare state
}

\author{
Martin McKee and David Stuckler watch aghast as American examples are followed to destroy \\ the European model of the welfare state
}

\author{
Martin McKee professor of European public health ${ }^{1}$, David Stuckler university lecturer ${ }^{2}$
}

${ }^{1}$ Faculty of Public Health and Policy, London School of Hygiene and Tropical Medicine, London WC1E 7HT, UK; ${ }^{2}$ Department of Sociology, University of Cambridge, Cambridge, UK

Christmas is a time to count our blessings, reflecting how they came to be. For people living in England this reflection is more relevant than ever, as the coalition government paves the way for the demise of the welfare state. This statement will be seen by many as reckless scaremongering. The welfare state, not only in Britain but also throughout western Europe, has proved extremely resilient. ${ }^{1}$ How could any government bring about such a fundamental change?

To answer this question it is necessary to go back to the 1940s, when Sir William Beveridge called for a national fight against the five "giant evils" of want, disease, ignorance, squalor, and idleness. ${ }^{2}$ His call secured support from across the political spectrum. Although he sat in the House of Commons as a Liberal, his plans were implemented by a Labour government, and continued under successive Conservative ones. ${ }^{3}$ The reasons for such wide ranging support varied but, for many ordinary people, the fundamental role of the welfare state was to give them security should their world collapse around them.

There were good reasons to seek security. The British people had just emerged from a war that had shown that, regardless of how high they were on the social ladder, they could fall to the bottom in an instant. The death and destruction of war were not the only threats; a serious illness could blight a family's prospects. People wanted to be sure that they would not be on their own if disaster struck, and they were prepared to ensure this through taxes and insurance contributions. They were, literally, "all in it together," accepting rationing of food and fuel to guarantee that in the face of austerity, everyone had access to the essentials.

In the 1970s, the philosopher John Rawls developed this concept into what he called a "theory of justice." ${ }^{4} \mathrm{He}$ argued that a fair society was one designed as if from behind a "veil of ignorance," meaning that class and social forces were removed from policy making. As he put it, behind the veil, "no one knows his place in society, his class position or social status, nor does anyone know his fortune in the distribution of natural assets and abilities, his intelligence, strength, and the like." Rawls argued that in such circumstances decision makers would create a society that does not privilege one group over another, as no one can know where they will end up. This uncertainty about the future was a fair approximation of what many people had experienced during the war.

The postwar situation was quite different in the United States, for several reasons. The country emerged from the war with a powerful corporate sector, enriched by military spending, that could shape the political discourse in its own interests. In much of Europe, industry was devastated, and in Germany and the countries it had occupied, many major corporations were tainted by collaboration. ${ }^{56}$ However, a crucial and longstanding difference was the role of race in society. In America, the rich could never fall to the bottom of the ladder, because that position was already taken. African Americans faced persistent and widespread discrimination. There was no veil of ignorance. Europeans knew they could go to bed rich and wake up poor, but a rich (and, by extension, white) American could be confident that they would never wake up black.

The consequences are apparent at all levels of American society today. In household surveys, support for welfare among white Americans is influenced by the race of the poor people who live around them: if their neighbours are white they are more inclined to generosity than if their neighbours are African-American. ${ }^{7}$ Although inequality is diminishing across ethnic groups (just as it is has risen across classes), ${ }^{8}$ the legacy of racial division continues to undermine support for social welfare. In states with a high proportion of African Americans, welfare payments are much less generous ${ }^{9}$ (an illustration of the "inverse care law"). ${ }^{10}$ Thus, one concern in explaining this American exceptionalism ${ }^{11}$ is that welfare is not seen as insuring one's family against 
catastrophe but rather as a payment to people with whom one has little shared identity. In this way, society becomes divided into "deserving" and "undeserving" groups of the poor.

A second difference is that Americans have been much more likely than Europeans to attribute poverty to laziness rather than misfortune (a form of victim blaming). ${ }^{12}$ If the rich wish to help the poor they are urged to use philanthropy, encouraged by the tax system and facilitated by a strong religious culture and distrust of the state. However, voluntary giving means that the donors can select the beneficiaries of their largesse, rather than leaving the choice to a democratic system. More than a third of social spending in the US comes from voluntary giving, whereas the comparable figure was less than one tenth in the pre-2004 European Union. ${ }^{13}$

A third factor is the relative absence of a countervailing discourse, reflecting the absence of a strong left wing or trade union voice. The entrenched dominance of the American two party system stymies the development of left wing political parties, while the geographical dispersion of population during the 19th century constrained the ability of a national trade union movement to organise. ${ }^{8}$ Industrialised countries with a greater fraction of workers in unions, one indicator of the power of the political left, invest more in social welfare (figure $\Downarrow$ ).

Understanding where the money comes from is only half the picture of the welfare system. The final main difference between the United States and Europe relates to what the wealthy get back from the state. This is much less in the US than in Europe. In every area the US is less generous; from education, to healthcare, to unemployment benefits. On average, the US invests about $\$ 3170$ ( $£ 2031 ; € 2370$ ) per person less than would be expected if it were a member of the pre-2004 European Union, given its national income (authors' calculations). ${ }^{14}$ In other words, the state is not there to help the rich and, in many respects, it is doing less than ever-for example, by disinvesting in public universities. ${ }^{14}{ }^{15}$ Thus, the state does not offer a system of mutual security. Instead it provides a basic safety net, albeit an increasingly threadbare one. The advantage of the American system, if you are rich, is that you can pay much less in taxes. Indeed, the low tax/low welfare system is so skewed that a billionaire will pay a much smaller proportion of income in taxes than the poorest paid workers, so that effectively the poor are subsidising the rich. ${ }^{16}$

By contrast, in Scandinavia, taxes are high but, in return, the rich obtain a comprehensive package of high quality benefits either free or at minimal cost, including child care, healthcare, social care, and university education. There is a clear trade-off: you pay higher taxes but you get more back in return (as well as living in a more harmonious, safer society). ${ }^{17}$

So for those who wish to destroy the European model of welfare state, the structural weaknesses of social welfare in the United States offer an attractive model. First, create an identifiable group of undeserving poor. Second, create a system in which the rich see little benefit flowing back to them from their taxes. Third, diminish the role of trade unions, portraying them as pursuing the narrow interests of their members rather than, as is actually the case, recognising that high rates of trade union membership have historically benefited the general population. ${ }^{18}{ }^{19}$ Finally, as Reagan did when cutting welfare in the $1980 \mathrm{~s},{ }^{1}$ do so in a way that attracts as little attention as possible, putting in place policies whose implications are unclear and whose effects will only be seen in the future. All these strategies can be seen in the UK today.

The tabloid press, much of it owned by multi-millionaires, is at the forefront of the first approach. Each day they fill their pages with accounts of people "milking the system." By constant repetition they create new forms of word association, constructing a cultural underclass. "Welfare" is invariably associated with "scroungers." "Bogus" invariably describes "asylum seekers." ${ }^{21}$ They accept that there is a group of deserving poor, whose situation has arisen from "genuine misfortune" (which seemingly excludes refugees caught up in wars), but when these groups appear in their pages it is because they have been let down by the state, which is devoting its efforts to the undeserving. And as a growing body of research shows, this continuous diet of hate does make a difference. ${ }^{22-24}$ Such vilification of the undeserving poor is not new. What is changing in the United Kingdom is the progressive exclusion of the middle classes from the welfare state through incremental erosion of universal benefits. The logic is appealing, but highly divisive: Why should the state pay for those who can afford to pay for themselves? Why should "ordinary working people" pay for "middle class benefits"? The economic crisis has given the government a once in a lifetime opportunity. As Naomi Klein has described in many different situations, those opposed to the welfare state never waste a good crisis. ${ }^{25}$ The deficit must be reduced, and so, one by one, benefits are removed and groups are pitted against each other, as the interests of the middle class in the welfare state wither away.

The first cut was to universal child benefit. This has been paid to all mothers, regardless of family income. It recognised the importance of children to society as a whole, not just to an individual family. It was also cheap, simple to administer, and free from anomalies. The government will now restrict child benefits to anyone in a family where one person is a higher rate tax payer. The problems were apparent from the start. A family with four children and two wage earners, each earning just below the higher rate tax threshold, would earn a total of up to $£ 84$ 950 per year, supplemented by child benefit of $£ 3146$. A similar sized family in which only one parent worked but earned just over the tax threshold, at $£ 42475$, would get nothing. If that parent was a widower, they would lose a further $£ 5077$ Widowed Parent's Allowance, which is linked to child benefit, resulting in an $18 \%$ drop in income. Only a saint would avoid asking why they pay their taxes at all in such circumstances.

The next thing to go was affordable university education. This was more difficult. The government first had to make the case that a university education was mainly a personal benefit, rather than a societal one. Graduates could expect higher incomes, on average, so they should pay for the privilege. The contribution they would make to society, as doctors, teachers, social workers, or in myriad other ways counted for nothing. The government argued that publicly funded education was unaffordable, yet the new system will be more expensive than what it replaced. ${ }^{26}$ But this is viewed as a price worth paying to remove a universal benefit. Moreover, students faced with years of personal debt know that some of their fees are being used to provide bursaries for poorer students. It is easy to see how, as they struggle to pay back their debt, this generation may also ask why they are paying taxes.

These recent assaults on universal programmes are just the start. Ministers have made it clear that they see railways, which since privatisation have required much greater public subsidies, as "rich man's toy". ${ }^{27}$ We are fed statistics showing that those who travel by train tend to earn above average income, so fares must rise above inflation. Of course, the reason (we are told) that the privatised railways are by far the most expensive in Europe is not because their shareholders are making excessive profits from what is in effect a state guaranteed monopoly but rather because of restrictive practices by trade unions, an argument 
that helps to erode support for them even further. Why should the ordinary commuter pay taxes to support this undeserving workforce as well as ever increasing fares?

The Mirrlees Review on the tax system, commissioned by the Institute for Fiscal Studies, has highlighted what it sees as an anomaly, whereby many of life's necessities, such as food, as well as things that make life a bit more civilised, such as books, are free from value added tax. It argues that this universal policy should be redressed and, if it causes hardship, then the poor (although it admittedly does not preface this with "undeserving" but by now most readers will get the message) should receive subsidies to help them. ${ }^{28}$ Once again, the ordinary shopper will ask why they should be paying taxes.

The direction of travel should now be clear. More and more, the middle classes will ask why they are paying into a system that gives them little back. The idea that the state is an insurance system, from which they can benefit if they are in need, is steadily eroded. Even the word "insurance" will be taken out in chancellor George Osborne's plans to merge national insurance with taxation. There will be ever greater reductions in the funding, and inevitably the quality, of those remaining services used by the middle classes, such as primary and secondary education and healthcare, persuading them that they would be better off seeking private options. Public services will become like public hospitals in the United States, a service for the poor. As Richard Titmuss famously said, a "service for the poor" inevitably becomes "a poor service," as the vocal and politically active middle class abandon the system. ${ }^{29}$ The ground rules are already being laid in healthcare, as the health secretary has sought to weaken his responsibility for a comprehensive health system. At some stage in the future any vestigial safeguards could disappear and commissioning consortiums, by then funded from personalised budgets, would become, in effect, insurance companies, with all sorts of ways to limit whom they enrol and what they cover.

Who benefits from this progressive degradation of the welfare state? Obviously not the lower classes. But nor do the middle classes, as the new, complex, and individualised systems are more expensive than what existed previously, often of poorer quality, and invariably far more complicated. The real beneficiaries are the very rich, who no longer have to pay for services they never used anyway.

Will the British people allow the welfare state to be dismantled? Not yet. But the situation could easily change. The experience of the United States shows how easily people can be persuaded to vote against their own economic interests. ${ }^{24}$ By visualising the stark reality of the future that may lie ahead of us we may be forced to challenge our own complacency. In this way, we can only try to emulate the "spirit of Christmas yet to come" in Dickens' Christmas Carol and hope that we will have the same happy result. ${ }^{30}$
This paper was drafted by MMcK and revised by DS, following a request from Tony Delamothe. It draws extensively on a speech given by MMcK to the Public Health Association of Australia in September 2011

Competing interests: All authors have completed the ICMJE uniform disclosure form at www.icmje.org/coi_disclosure.pdf (available on request from the corresponding author) and declare: no support from any organisation for the submitted work; no financial relationships with any organisations that might have an interest in the submitted work in the previous three years; no other relationships or activities that could appear to have influenced the submitted work.

Provenance and peer review: Commissioned, externally peer reviewed.

1 Pierson P. The new politics of the welfare state. World Polit 1996;48:143-79.

2 Beveridge W. Social insurance and allied services. HMSO, 1942.

3 Timmins N. The five giants: a biography of the welfare state. HarperCollins, 1995.

Rawls J. A theory of justice. Oxford University Press, 1973.

5 Fenby J. The general: Charles De Gaulle and the France he saved. Simon and Schuster, 2010.

6 Borkin J. The crime and punishment of I G Farben. Free Press, 1978.

7 Luttmer EFP. Group loyalty and the taste for redistribution. J Polit Econ 2001; 109: 500-28.

8 Stille A. The paradox of the new elite. 2011. www.nytimes.com/2011/10/23/opinion/sunday/ social-inequality-and-the-new-elite.html? $r=3 \&$ pagewanted=all\%3Fsrc\%3Dtp\&smid=fbsocial-in

9 Alesina A, Glaeser EL. Fighting poverty in the US and Europe: a world of difference. Oxford University Press, 2004

10 Tudor Hart J. The inverse care law. Lancet 1971;297:405-12

11 Lipset SM. American exceptionalism: a double-edged sword. Norton, 1996.

12 Alesina A, Glaeser EL, Sacerdote B. Why doesn't the US have a European-style welfare system? National Bureau of Economic Research, 2001.

13 Organisation for Economic Co-operation and Development. 2011. http://stats.oecd.org.

14 Newfield C. Unmaking the public university: the forty-year assault on the middle class. Harvard University Press, 2011.

15 Meister B. Debt and taxes: can the financial industry save public universities? Representations 2011;116:128-55.

16 Wearden G. Warren Buffett calls for higher taxes for US super-rich. 2011. www.guardian. co.uk/business/2011/aug/15/warren-buffett-higher-taxes-super-rich.

17 Esping-Anderson G. The three worlds of welfare capitalism. Princeton University Press, 1990.

18 Navarro V. Why some countries have national health insurance, others have national health services, and the US has neither. Soc Sci Med 1989;28:887-98.

19 Huber E, Ragin C, Stephens JD. Social democracy, christian democracy, constitutional structure, and the welfare state. Am J Sociol 1993;99:711-49.

20 Boffey D. Welfare to Work policy "casts the disabled as cheats." 2011. /www.guardian. co.uk/society/2011/jul/24/welfare-policy-incites-hatred-disabled.

21 Lynn N, Lea S. A phantom menace and the new apartheid: the social construction of asylum-seekers in the United Kingdom. Discourse Society 2003;14 425-52.

22 Della Vigna S, Kaplan E. The Fox News effect: media bias and voting. NBER Working Paper No 12169. NBER, 2006.

23 Westen $\mathrm{D}$. The political brain: the role of emotion in deciding the fate of the nation. Public Affairs, 2008.

24 Frank T. What's the matter with Kansas? How conservatives won the heart of America. Metropolitan Books, 2004

25 Klein N. The shock doctrine: the rise of disaster capitalism. Penguin, 2008.

26 Richardson H. MPs warn over tuition fees funding gap. 2011. www.bbc.co.uk/news/ education-13667117.

27 Millward D. Trains "rich man's toy" admits transport secretary. 2011. www.telegraph.co. uk/news/uknews/road-and-rail-transport/8760912/Trains-rich-mans-toy-admits-TransportSecretary.html.

28 Mirrlees J, Adam S, Besley T, Blundell R, Bond S, Chote R, et al. Tax by design: the Mirrlees Review. Oxford University Press, 2011.

29 Titmuss R. Essays on the welfare state. London: Unwin Hyman, 1958

30 Dickens C. A Christmas carol. Wordsworth Editions, 1993.

Cite this as: BMJ 2011;343:d7973

(c) BMJ Publishing Group Ltd 2011 


\section{Figures}

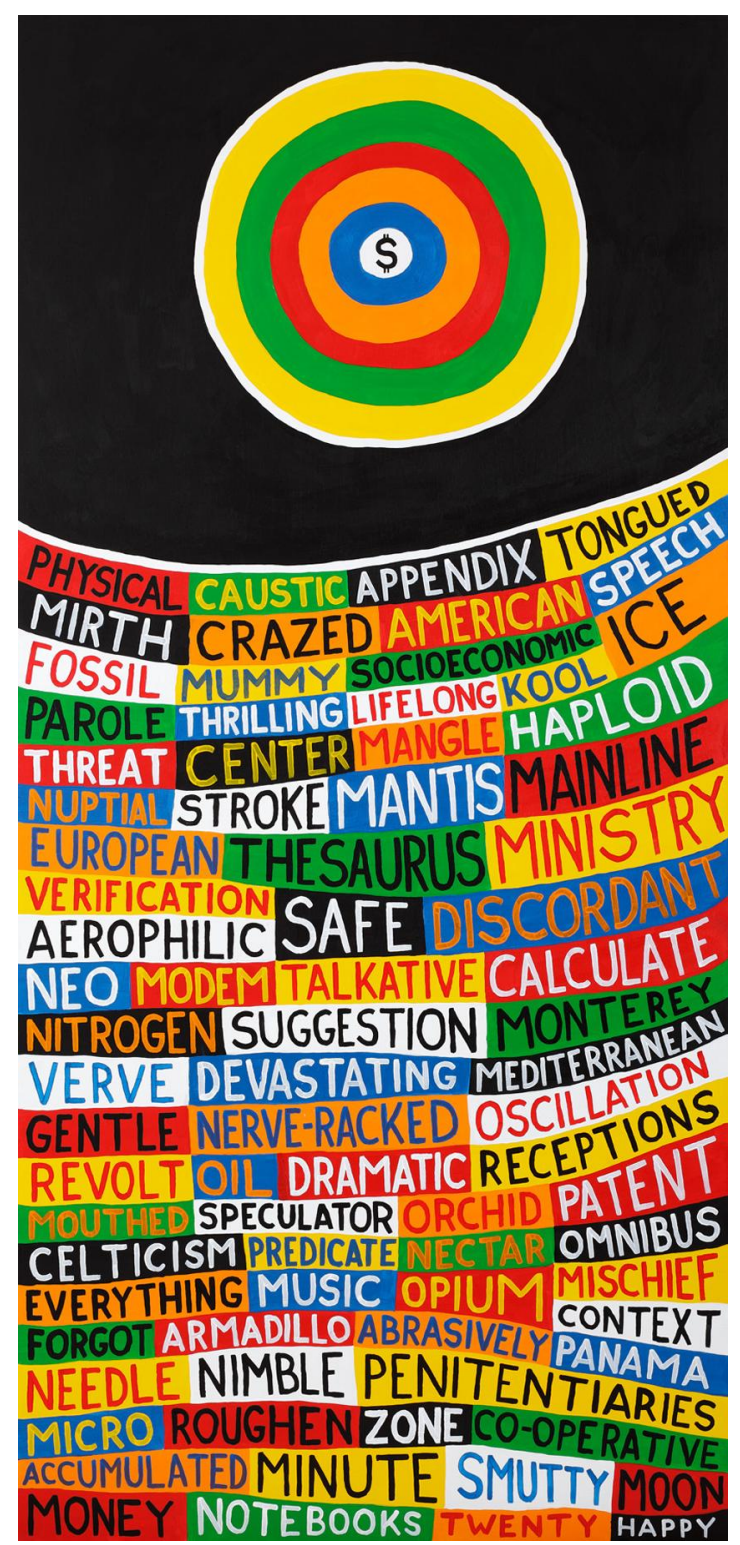

Over Normal by Stanley Donwood/www.slowlydownward.com 


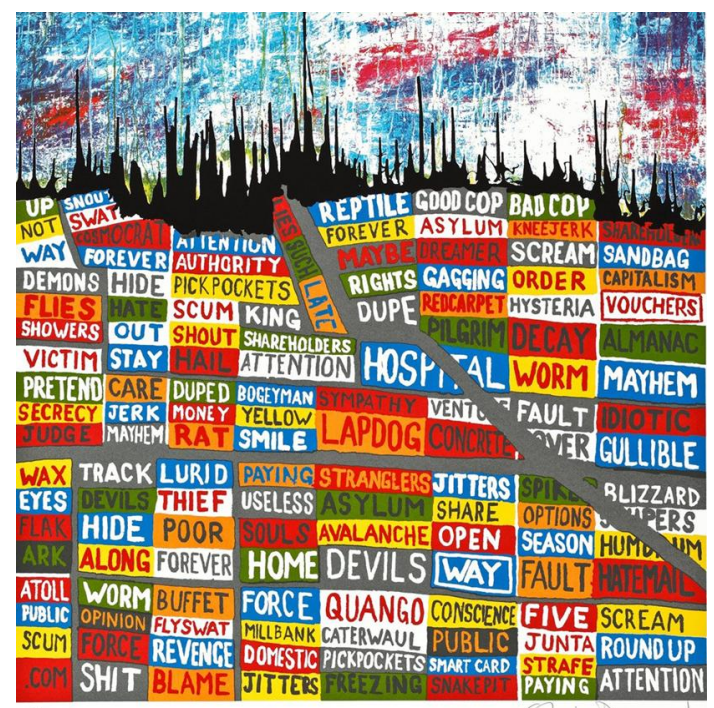

LA, 2011 by Stanley Donwood/TAG Fine Arts

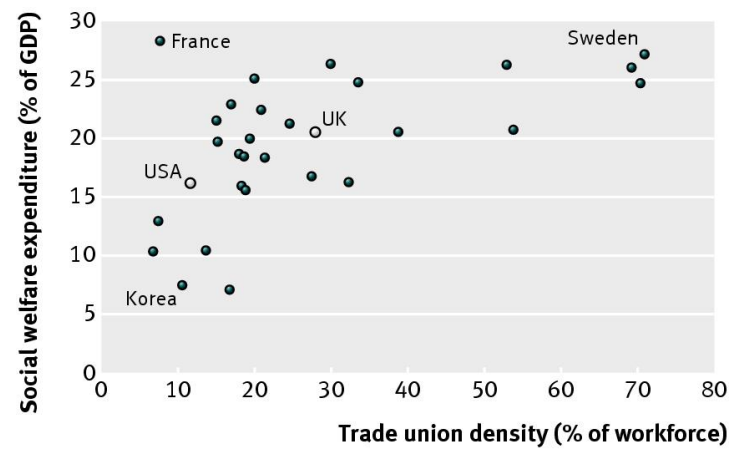

Association between unionisation and social welfare in the year 2007 in 29 countries of the Organisation for Economic Co-operation and Development (OECD). Source: authors' calculations using OECD 2011 data. Public social welfare expenditure includes funds in healthcare, old age support, incapacity related support, survivorship benefits, unemployment and active labour market programmes, housing support, and other social policy areas. $R=0.53, P=0.0027$ 


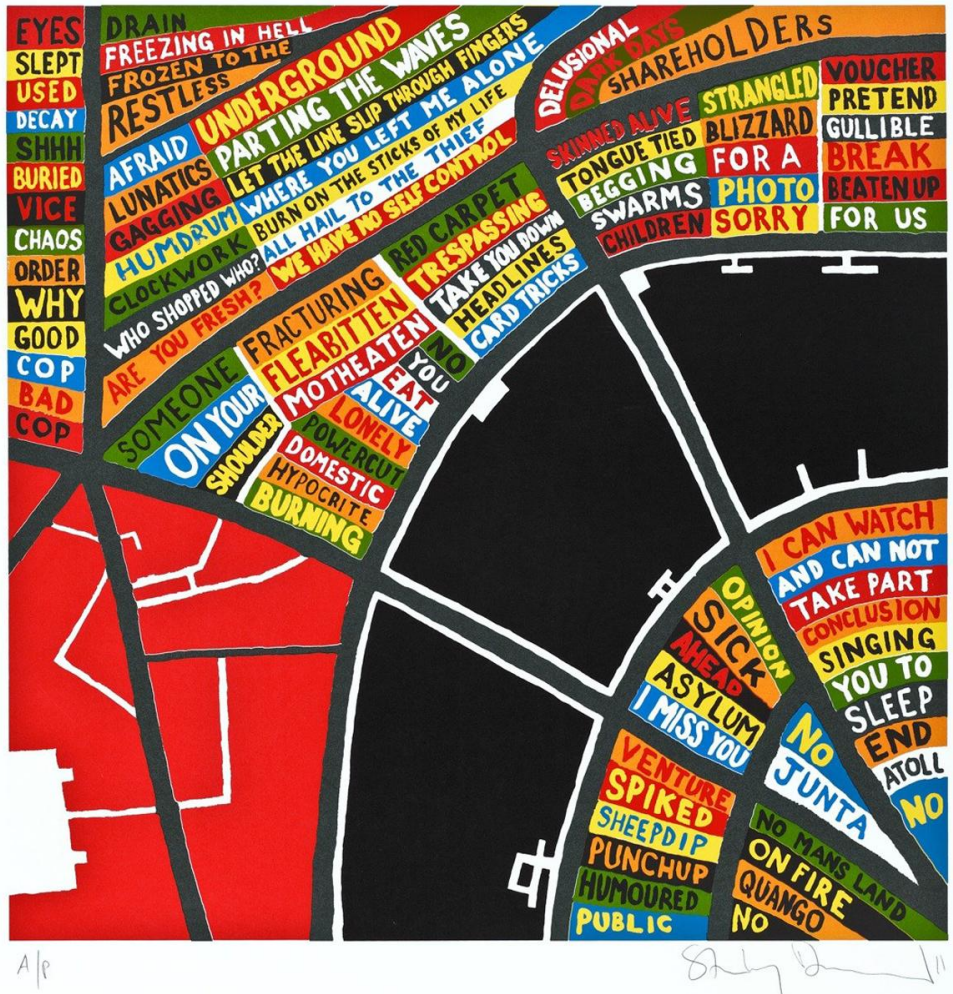

London, 2011 by Stanley Donwood/TAG Fine Arts 